\title{
KARAKTERISTIK IBU BERSALIN DENGAN TERJADINYA RETENSIO PLASENTA DI PUSKESMAS BABUSSALAM KABUPATEN ACEH TENGGARA
}

\author{
Fika Lestari ${ }^{1}$, Purnama Sari Cane ${ }^{2}$, Joharsah ${ }^{3}$ \\ 1,2,3 Akademi Kebidanan Nurul Hasanah Kutacane \\ Email: afiqalove@gmail.com, purnamasari.cane@gmail.com,joharsah87@gmail.com
}

\begin{abstract}
Causes and post partum bleeding include placental retention which reached $16 \%-17 \%$ in 2016. Placental retention was a condition in which the placenta is not born within 1 hour after the baby is born. The purpose of this study was to find out the relationship between maternal characteristics and the occurrence of placental retention. The research was conducted at Babussalam Health Center with a sample number of 22 people with this type of analytical survey research and cross sectional design. The results of the study could be seen with the Chi Square test with a confidence level of 95\%, and a $=0.05$, based on the parity it is known that X2 calculates > X2 table $(14,157>7.815)$ then there is a relationship between parity and the occurrence of placental retention. Based on the age of daketahul X2 calculated $>X 2$ table $(13,093>5,991)$ then there is a relationship between the mother's age and the occurrence of placental retention. Based on the state of the uterus known X2 calculates $>X 2$ table $(10,092>3,841)$ then there is a relationship between the state of the mother's uterus and the occurrence of placental retention. Based on the sticking of the table is known X2 calculates >X2 table (9,322 > 5,991) it can be concluded that Ha was accepted and Ho was rejected. So there is a relationship between placental attachment and placental retention. There is a characteristic relationship of maternity mothers with the occurrence of placental retention. It is expected to the mother to keep her pregnancy distance and if the mother's age is > 35 years and already have more children and 3 should the mother not get pregnant again because it will be very risky to the mother and fetus.
\end{abstract}

\section{Keywords: Maternal characteristics, placental retention, post partum bleeding}

\section{PENDAHULUAN}

Penurunan angka kematian ibu per 100 ribu kelahiran bayi hidup masih terlalu lamban untuk mencapai target Tujuan Pembangunan Millenium (Millenium

Development

Goals/MDGs) dalam rangka mengurangi tiga perempat jumlah perempuan yang meninggal selama hamil dan melahirkan pada 2015, demikian pernyataan resmi Organisasi
Kesehatan Dunia (WHO). Dalam pernyataan resmi WHO dijelaskan, untuk mencapai target MDGs penurunan angka kematian ibu antara 1990 dan 2015 seharusnya 5,5 persen per tahun. Namun data WHO, UNICEF, UNFPA dan Bank Dunia menunjukkan angka kematian ibu hingga saat ini masih kurang dari satu persen pertahun. Pada 2015, sebanyak 536.000 perempuan meninggal dunia akibat masalah persalinan, lebih rendah dari jumlah kematian ibu tahun 2016 yang 
sebanyak 576.000. Menurut data WHO, sebanyak 99 persen kematian ibu akibat masalah persalinan atau kelahiran terjadi di negara-negara berkembang. Rasio kematian ibu di negara-negara berkembang merupakan yang tertinggi dengan 450 kematian ibu per 100 ribu kelahiran bayi hidup jika dibandingkan dengan rasio kematian ibu di sembilan negara dan 51 negara. (Afrizal, 2012)

Angka Kematian Ibu (AKI) merupakan salah satu indikator untuk melihat derajat kesehatan perempuan. Angka kematian ibu juga merupakan salah satu target yang telah ditentukan dalam tujuan pembangunan millenium yaitu tujuan ke 5 yaitu meningkatkan kesehatan ibu dimana target yang akan dicapai sampai tahun 2015 adalah mengurangi sampai $3 / 4$ resiko jumlah kematian ibu. Dari hasil survei yang dilakukan AKI telah menunjukkan penurunan dari waktu ke waktu, namun demikian upaya untuk mewujudkan target tujuan pembangunan millenium masih membutuhkan komitmen dan usaha keras yang terus menerus. (Departemen Kesehatan, 2018)

Berdasarkan SDKI survei terakhir tahun 2017 AKI Indonesia sebesar 228 per 100.000 Kelahiran Hidup, meskipun demikian angka tersebut masih tertinggi di Asia.
Sementara target Rencana Pembangunan Jangka Menengah Nasional (RPJMN) ada sebesar 226 per 100.000 Kelahiran Hidup. (Departemen Kesehatan, 2018)

Penyebab kematian ibu melahirkan yang sering terjadi yakni pendarahan, hipertensi saat hamil atau pre-eklamasi dan infeksi. Sementara itu, pendarahan menempati persentase tertinggi penyebab kematian ibu (28\%). Di berbagai negara paling sedikit seperempat dari seluruh kematian ibu disebabkan oleh pendarahan; proporsinya berkisar antara kurang dari $10 \%$ sampai hampir 60\%. Walaupun seorang perempuan bertahan hidup setelah mengalami pendarahan pasca persalinan, namun ia akan menderita akibat kekurangan darah yang berat (anemia berat) dan akan mengalami masalah kesehatan yang berkepanjangan. (Departemen Kesehatan, 2018)

Wanita yang melahirkan anak pada usia dibawah 20 tahun atau lebih dari 35 tahun merupakan faktor resiko terjadinya perdarahan pasca persalinan yang dapat mengakibatkan kematian maternal. Hal ini dikarenakan pada usia dibawah 20 tahun fungsi reproduksi seorang wanita belum berkembang dengan sempurna, sedangkan pada usia diatas 35 tahun fungsi reproduksi seorang wanita sudah mengalami penurunan dibandingkan fungsi reproduksi normal sehingga kemungkinan untuk terjadinya komplikasi pasca persalinan terutama perdarahan akan lebih besar. (Afrizal, 2012) 
Paritas merupakan faktor resiko yang mempengaruhi perdarahan post partum. Pada paritas yang rendah (paritas 1) dapat menyebabkan ketidaksiapan ibu dalam menghadapi persalinan sehingga ibu hamil tidak mampu dalam menangani komplikasi yang terjadi selama kehamilan, persalinan dan nifas. Sedangkan semakin sering wanita mengalami kehamilan dan melahirkan (paritas lebih dari 3) maka uterus semakin lemah sehingga besar resiko komplikasi kehamilan. Paritas 2-3 merupakan paritas paling aman ditinjau dari sudut perdarahan pasca persalinan yang dapat mengakibatkan kematian maternal. Paritas satu dan paritas tinggi (lebih dari 3) mempunyai angka kejadian perdarahan pasca persalinan lebih tinggi. (Manuaba, 2018)

Menurut penelitian Yuliati, (2017) menyatakan proporsi ibu yang mengalami perdarahan post partum dengan paritas 1 sebesar $12 \%$, paritas 2-3 sebesar $40 \%$ dan paritas lebih dari 3 sebesar $48 \%$. Demikian juga dengan penelitian Milaraswati (2018) menyatakan bahwa proporsi ibu yang mengalami perdarahan post partum dengan paritas > 4 yaitu $69 \%$.

Menurut penelitian Hazmi, (2015) bahwa pada tingkat kepercayaan $95 \%$ ibu yang berumur di bawah 20 tahun atau di atas 30 tahun memiliki risiko mengalami perdarahan postpartum 3,3 kali lebih besar dibandingkan ibu yang berumur 20 sampai 29 tahun. Selain itu penelitian ini menyatakan bahwa pada tingkat kepercayaan 95\% umur ibu di bawah 20 tahun dan diatas 35 tahun bermakna sebagai faktor risiko yang memengaruhi perdarahan postpartum. (Hazmi, 2015)

Penyebab dari perdarahan post partum diantaranya adalah retensio plasenta yaitu mencapai 16\%-17\%. Retensio plasenta merupakan keadaan dimana plasenta belum lahir dalam waktu 1 jam setelah bayi lahir. Di Negara egara berkembang maupun negara maju angka kejadian perdarahan post partum mencapai $5 \%$ sampai $15 \%$. Sedangkan (Chapman, 2016) mengungkapkan bahwa insiden retensio plasenta mencapai 3\% dari persalinan pervaginam. $15 \%$ retensio plasenta terjadi pada ibu yang pernah mengalami retensio plasenta.

Berdasarkan laporan bulanan dari bidan desa di Puskesmas Babussalam diketahui bahwa kejadian perdarahan akibat retensio plasenta pada tahun 2021 mencapai 13 kasus sedangkan berdasarkan catatan pada bulan Januari s.d Juni 2021 jumlah ibu melahirkan di seluruh Poskesdes dan Pustu wilayah kerja Puskesmas Babussalam dengan jumlah persalinan 243 pasien, dengan distribusi 213 dengan persalinan normal, 7 pasien dengan operasi saesar, sedangkan pasien bersalin yang mengalami kejadian PPH berjumlah 23 pasien, dari 23 yang 
mengalami perdarahan 9 diantaranya mengalami retensio plasenta.

\section{METODE}

Jenis penelitian ini adalah study retrospektif yaitu penelitian yang dilakukan sesaat, artinya objek penelitian diamati pada waktu lampau.

Desain penelitian adalah cross sectional.

Populasi dalam penelitian ini seluruh ibu melahirkan yang pernah mengalami retensio plasenta di Puskesmas Babussalam sebanyak 22 orang. Penelitian dilakukan pada Januari s/d Juni 2021. Sampel dalam penelitian ini dengan menggunakan teknik total populasi yaitu seluruh populasi dijadikan sampel penelitian. Jumlah sampel penelitian sebanyak 22 responden.

Pengumpulan data penelitian dengan mengunakan kueioner yang dibagikan langsung kepada responden dalam waktu yang telah ditentukan. Analisa yang digunakan dalam penelitian adalah Analisa univariat dan bivariat. Uji analisa data dengan menggunakan uji chi-square dengan menggunakan perangkat SPSS. (Budiarto, 2012)

\section{HASIL DAN PEMBAHASAN}

Analisa univariat untuk menggambarkan penyajian data dari beberapa variabel dalam bentuk tabel distribusi frekuensi meliputi paritas, umur, keadaan uterus, perlengketan, plasenta, dan retensio plasenta. Berdasarkan hasil penelitian yang telah dilakukan di puskesmas Babussalam, Kabupaten Aceh Tenggara. Tahun 2021, maka di peroleh data sebagai berikut :

Tabel 1 Distribusi frekuensi berdasarkan paritas, umur, keadaan uterus, perlengketan plasenta, dan ratensio plasenta di Puskesmas Babussalam, Kabupaten Aceh Tenggara

\begin{tabular}{clrl}
\hline No. & \multicolumn{1}{c}{ Variabel } & (n) & $(\mathbf{\%})$ \\
\hline $1 \quad$ Paritas & & \\
& a) Primipara & 3 & 13,6 \\
& b) Sekundipara & 6 & 27,3 \\
& c) Multipara & 9 & 40,9 \\
& d) grandemultipara & 4 & 18,2 \\
\hline \multicolumn{2}{l}{ Total } & $\mathbf{2 2}$ & $\mathbf{1 0 0}$ \\
\hline & Umur & &
\end{tabular}

\begin{tabular}{lcc} 
a) $<20$ tahun & 1 & 4,5 \\
b) $20-35$ tahun & 15 & 68,2 \\
c) $>35$ tahun & 6 & 27,2 \\
\hline Total & $\mathbf{2 2}$ & $\mathbf{1 0 0}$ \\
\hline
\end{tabular}

3 Keadaan uterus

\begin{tabular}{lcc} 
a) Normal & 15 & 68,2 \\
b) Tidak normal & 7 & 31,8 \\
\hline Total & $\mathbf{2 2}$ & $\mathbf{1 0 0}$ \\
\hline Perlengketan & & \\
plasenta & & \\
a) Adhesive & 17 & 77,3 \\
b) Inkreta & 4 & 18,2 \\
c) Akreta & 1 & 4,5 \\
\hline Total & $\mathbf{2 2}$ & $\mathbf{1 0 0}$ \\
\hline
\end{tabular}

Retensio plasenta

\begin{tabular}{ccc} 
a) Ringan & 16 & 72,7 \\
b) Sedang & 6 & 27,3 \\
\hline Total & $\mathbf{2 2}$ & $\mathbf{1 0 0}$ \\
\hline
\end{tabular}

Dari tabel diatas dilihat berdasarkan paritas dari 22 orang ibu yang mengalami ratensio plasenta, mayoritas ibu multipara yaitu 9 orang $(40,9 \%)$ dan minoritas ibu primipara yaitu 3 orang (13,6\%). Berdasarkan umur, mayoritas ibu yang 
mengalami ratensio plasenta umur 2035 tahun yaitu 15 orang $(68,2 \%)$ dan minoritas berumur $<20$ tahun yaitu 1 orang $(4,5 \%)$.

Berdasarkan keadaan uterus mayoritas ibu yang retensio plasenta adalah yang uterus nya normal yaitu 15 orang $(68,2 \%)$ dan monoritas uterus yang tidak normal yaitu 7 orang $(31,8 \%)$. Berdasarkan perlengketan plasenta mayoritas ibu mengalami perlengketan adhesive yaitu 17 orang $(77,3 \%)$ dan minoritas perlengketan akreta yaitu 1 orang $(4,0 \%)$. berdasarkan retensio plasenta ringan yaitu 16 orang $(72,7 \%)$ dan minoritas retensio berat yaitu 6 orang $(27,3 \%)$.

Analisa bivariat dilakukan untuk menggambarkan penyajian data dari dua variabel secara silang dengan menggunakan uji chi-square untuk melihat hubungan antara variabel dependen dengan variabel independen hubungan paritas ibu bersalin dengan terjadinya ratensio plasenta di Babussalam, Kabupaten Aceh Tenggara Tahun 2021, adapun hasil penelitian yang dilakukan tentang hubungan paritas dengan terjadinya retensio plasenta. bagai berikut:
Tabel 2 Hubungan paritas ibu bersalin dengan terjadinya retensio plasenta di Puskesmas Babussalam, Kabupaten Aceh Tenggara

\begin{tabular}{lcrrrrrrr}
\hline \multicolumn{8}{c}{ Retensio Plasenta } \\
\hline Paritas & \multicolumn{1}{l}{ Ringan } & \multicolumn{2}{l}{ Sedang } & \multicolumn{2}{l}{ Total } & df & P \\
\hline & $\mathrm{N}$ & $\%$ & $\mathrm{~N}$ & $\%$ & $\mathrm{~N}$ & $\%$ & & \\
\hline Primipara & 3 & 0 & 0 & 0 & 3 & 100 & & \\
$\begin{array}{l}\text { Sekun } \\
\text { dipara }\end{array}$ & 6 & 100 & 0 & 0 & 6 & 100 & & \\
Multipara & 6 & 77,8 & 2 & 22,2 & 9 & 100 & & 14,1 \\
$\begin{array}{l}\text { Grande } \\
\text { multipara }\end{array}$ & 7 & 0 & 4 & 100 & 4 & 100 & & 57 \\
\hline
\end{tabular}

Berdasarkan tabel diatas dapat diketahui bahwa dari 3 orang ibu primipira semuanya mengalami retensio plasenta ringan yaitu 3 orang $(100 \%)$. Dari 6 orang ibu sekundipara semuanya mengalami retensio plasenta ringan yaitu 6 orang (100\%) dari 9 orang ibu multipara mayoritas ibu mengalami retensio plasenta ringan yaitu 7 orang $(77,8 \%)$ dan minoritas mengalami retensio plasenta berat yaitu 2 orang (22,2 \%). Dari 4 orang ibu grandemultipara, semuanya mengalami retensio plasenta berat yaitu 4 orang ( $100 \%)$.

Berdasarkan pengujian dengan menggunakan hitung perbandingan chisquare dengan chi-square tabel diketahui bahwa $X^{2}$ hitung $=14,157$ dengan $\propto=0,05$ df $=3$ dan $X^{2}$ hitung $=14,157$ dengan $\propto=$ $0,05 \mathrm{df}=3$ dan $\mathrm{X}^{2}$ tabel $=7,815$. perbandingan chi-square hitung dengan chisquare tabel diketahui $\mathrm{X}^{2}$ hitung $>\mathrm{X}^{2}$ tabel ( 14, 157 > 7,815) maka dapat disimpulkan bahwa HA diterima dan HO di tolak . jadi ada hubungan antara paritas dengan terjadinya retensio plasenta hubungan umur 
ibu bersalin dengan terjadinya retensio plasenta di Puskesmas Babussalam, Kabupaten Aceh Tenggara Tahun
2021. Adapun hasil penelitian yang dilakukan tentang hubungan umur ibu dengan terjadinya retensio plasenta.

Tabel 3 Hubungan umur ibu bersalin dengan terjadinya retensio plasenta di Puskesmas Babussalam, Kabupaten Aceh Tenggara Tahun 2021

\begin{tabular}{|c|c|c|c|c|c|c|}
\hline \multirow[t]{3}{*}{ Umur } & \multicolumn{5}{|c|}{ Retensio Plasenta } & \multirow{3}{*}{$\mathrm{P}$} \\
\hline & Ringan & \multicolumn{2}{|c|}{ Sedang } & \multicolumn{2}{|c|}{ Total } & \\
\hline & $\mathrm{N} \%$ & $\mathrm{~N}$ & $\%$ & $\mathrm{~N}$ & $\%$ & \\
\hline$\leq 20$ tahun & 1100 & 0 & 0 & 1 & 100 & \\
\hline 21-35 tahun & 1493,3 & 1 & 6,7 & 15 & 100 & 13,093 \\
\hline$>35$ tahun & $1 \quad 16,7$ & 5 & 3,3 & 6 & 100 & \\
\hline
\end{tabular}

Berdasarkan tabel diatas dapat diketahui bahwa $\mathrm{X}^{2}$ hitung $=13,093$ dengan
diketahui bahwa ibu yang berumur < 20 tahun semuanya mengalami retensio plasenta yaitu 1 orang $(100 \%)$. Dari 15 orang yang berumur 21-35 tahun, mayoritas mengalami retensio plasenta ringan yaitu 14 orang $93,3 \%)$ dan minoritas 1 orang ( $6,7 \%)$. Dari 6 orang ibu yang berumur $>35$ tahun, mayoritas ibu mengalami retensio plasenta ringan yaitu 5 orang $(83,3 \%)$ dan minoritas mengalami retensio plasenta ringan yaitu 1 orang $(16,7 \%)$.

Berdasarkan pengujian dengan menggunakan perbandingan chisquare hitung dengan chi-square tabel

Tabel 4 Hubungan keadaan uterus ibu bersalin dengan terjadinya retensio plasenta di Puskesmas Babussalam, Kabupaten Aceh Tenggara Tahun 2021

\begin{tabular}{|c|c|c|c|c|c|c|c|}
\hline \multirow[t]{3}{*}{ Keadaan Uterus } & \multicolumn{6}{|c|}{ Retensio Plasenta } & \multirow[b]{2}{*}{$\mathrm{P}$} \\
\hline & Ringan & & Sedang & & Total & df & \\
\hline & $\mathrm{N}$ & $\%$ & $\mathrm{~N} \%$ & $\mathrm{~N}$ & $\%$ & & \\
\hline Normal & 14 & 93,3 & 6,7 & 15 & 100 & & \\
\hline Tidak normal & 2 & 28,6 & 71,4 & 7 & 100 & 1 & 10,092 \\
\hline
\end{tabular}

Berdasarkan tabel diatas dapat yang mengalami retensio plasenta, mayoritas diketahui bahwa dari 15 orang ibu ibu yang memiliki uterus yang normal 
mengalami retensio plasenta ringan yaitu 14 orang $(93,3 \%)$ dan minoritas mengalami retensio plasenta berat yaitu 1 orang ( $6,7 \%)$ dari 7 orang ibu yang mengalami retensio plasenta mayoritas ibu yang memiliki uterus yang tidak normal mengalami retensio plasenta berat yaitu 5 orang ( $71,4 \%$ ) dan minoritas ibu mengalami retensio plasenta ringan yaitu 2 orang $(28,6 \%)$

Berdasarkan pengujian dengan menggunakan perbandingan chi-square hitung dengan chi-square tabel diketahui bahwa $\mathrm{X}^{2}$ hitung $=13$, 092dengan tingkat kepercayaan $95 \% \propto=0,05 \mathrm{df}=1$ dan $\mathrm{X}^{2}$ tabel $=3,841$ perbandingan chi-square dengan chi-square tabel diketahui $\mathrm{X}^{2}$ hitung $>X^{2}$ tabel $(10,092>3,841)$ maka dapat disimpulkan bahwa HA diterima dan HO di tolak . jadi ada hubungan antara uterus ibu dengan terjadinya retensio plasenta.

\section{Tabel 5 Hubungan Perlengketan Plasenta Ibu Bersalin Dengan Terjadinya Retensio}

\section{Plasenta di Puskesmas Babussalam, Kabupaten Aceh Tenggara}

Adapun hasil penelitian yang dilakukan tentang hubungan perlengketen plasenta terjadinya retensio plasenta.

\begin{tabular}{llclclclc}
\hline \multicolumn{1}{l}{ Perlengketan Plasenta } & \multicolumn{7}{c}{ Retensio Plasenta } \\
\hline & Ringan & \multicolumn{2}{c}{ Sedang } & Total & df & $\mathrm{P}$ \\
\hline Adhesive & $\mathrm{N}$ & $\%$ & $\mathrm{~N}$ & $\%$ & $\mathrm{~N}$ & $\%$ & & \\
Inkreta & 15 & 88,2 & 2 & 11,8 & 17 & 100 & & \\
Akreta & 1 & 25 & 3 & 75 & 4 & 100 & 2 & 9,322 \\
& 0 & 0 & 1 & 100 & 1 & 100 & &
\end{tabular}

\section{Berdasarkan tabel diatas dapat} diketahui bahwa dari 17 orang ibu yang mengalami perlengketan plasenta adhesive mayoritas ibu mengalami retensio plasenta ringan yaitu 15 orang $(88,2 \%)$ dan minoritas mengalami retensio plasenta berat yaitu 2 orang $(11,8 \%)$ dari 4 orang ibu yang mengalami perlengketan plasenta inkreta mayoritas ibu mengalami retensio plasenta berat yaitu 3 orang (75 \%) dan minoritas mengalami perlengketan plasenta inkreta yaitu 1 orang $(25 \%)$ ibu yangmengalami perlengketan plasenta akreta semuanya mengalami retensio plasenta berat yaitu 1 orang ( $100 \%)$

Berdasarkan pengujian dengan menggunakan perbandingan chi-square hitung dengan chi-square tabel diketahui $\mathrm{X}^{2}$ hitung $=9,322$ dengan tingkat kepecayaan $95 \% \propto 0=0,05$ diketahui $X^{2}$ hitung $>X^{2}$ tabel $(9,322>5,991)$ maka dapat disimpulkan bahwa HA diterima dan HO di tolak jadi ada hubungan antara perlengketan plasenta terjadinya retensio plasenta.

Berdasarkan pengujian dengan menggunakan perbandingan Chi-Sguare hitung dengan chi-Squre tabel diketahui bahwa $\mathrm{x} 2$ hitung $=14,157$ dengan $\alpha=0,05$, 
df-3, dan $\mathrm{x} 2$ tabel $=7.815$. perbandingan Chi-Squre hintung dengan Chi-Squre tabel diketahui x2 hitung > x2 tabel $(14,157>7,815)$ maka dapat disimpulkan bahwa $\mathrm{Ha}$ diterima dan Ho ditolak. Jadi ada hubungan antara paritas dengan terjadinya retensio plasenta.

Berdasarkan tabel paritas ibu diketahui bahwa 3 dari ibu primipara mengalami retensio plasenta ringan. Hal ini diakibatkan oleh ibu primipara konstraksi uterusnya masih baik sehingga sisia plasenta cepat keluar dan pendarahan yang dialami oleh ibu ringan. Demikian halnya dengan ibu sekundipara, otot rahimnya masih kuat sehingga uterus dapat berkontraksi dengan baik dan pelasenta tidak terlalu lama keluar dan memungkinkan perdarahan yang ringan. Dari 9 ibu multipara yang mengalami retensio plasenta, 7 diantaranya perdarahan ringan, hal ini diakibatkan karena kondisi ibu masih baik, dan pada saat persalinan ibu tidak mengalami anemia dan adanya penangan yang cepat dari petugas kesehatan, sedengkan 2 orang ibu yang mengalami perdarahan sedang, saat melahirkan ibu mengalami anemia dan kontraksi uterus ibu yang tidak baik sehingga plasenta lebih lama lahir dan mengakibatkan perdarahan sedang.
Pada 4 orang ibu grandemultipara semuanya mengalmai perdarahan sedang. Hal ini diakibatkan karena otot rahim yang sudah lemah karena sudah telalu banyak mengalami kehamilan sebelumnya sehingga otot rahim tidak terlalu kuat menahan plasenta sehingga terjadi perdarahan sedang.

Hal ini sesuai dengan hasil penelitian yang dilakukan oelh Hanna (2012), ibu dengan paritas multipara dan grandemultipara dapat menyebabkan kejadian retensio plasenta sebesar 1.449 kali lipat dibandingkan dengan ibu dengan paritas primipara. Pada multipara, keadaan endometrium pada daerah korpus uteri telah mengalami degenaris dan nekrosis, menurunnya kemampuan dan fungsi tubuh disebabkan kematian sejumlah besar sel pada jaringan endometrium sebagai tempat implatasi plasenta endometrium korpus uteri pada multipara menyebabkan daerah endometrium menjadi tidak subur lagi sehingga pemberian oksigenisasi ke hasil konsepsi akan terganggu dan memungkinkan plasenta untuk menanamkan diri lebih dalam untuk memenuhi kebutuhan janin yang dilahirkan mengakibatkan tertahannya zigot korion plasenta di miometrium atau disebut juga retensio plasenta. Korpus uteri merupakan bagian atas rahim yang mempunyai otot paling telbal, sehingga dalam keadaan normal plasenta berimplasenta pada daerah korpus uteri. 
Menurut asumsi peneleti retensio plasenta merupakan salah satu penyebab perdarahan kala III yang berakibatkan kematian ibu, jika tidak ditangani dengan baik, dengan tertahannya plasenta di dalam kavum uteri, maka uterus tidak dapat berkontraksi secara maksimak,yang pada akhirnya keadaan ini menyebabkan terjadinya perdarahan. Hal ini biasanya terjadi pada ibu multipara dan ibu grandemultipara karena banyaknya persalinan atau paritas yang banyak dan jarak persalinan yang terlalu dekat membuat uterus yang tidak memungkinkan palsenta berimplasenta.

\section{Berdasarkan}

pengujian menggunakan perbandingan Chi-Squre hitung dengan Chi-Squre tabel deketahui bahwa x2 hitung $=13,093$ dengan tingkat kepercayaan $95 \% \quad \alpha=$ $0,005, \mathrm{df}=2$, dan $\mathrm{x} 2$ tabel $=5,991$. Perbandingan Chi-Squre hitung dengan Chi-Squre tabel diketahui x2 hitung > x2 tabel $(13,093>5,991)$ maka dapat disimpulkan bahwa $\mathrm{Ha}$ diterima dan Ho ditolak. Jadi ada hubungan umur ibu dengan terjadinya retensio plasenta.

Pada Tabel Umur Ibu diketahui bahwa ibu yang bermuru < 20 tahun mengalami retensio plasenta ringan. Hal ini diakibatkan karena kondisi ibu yang baik, dan penanganan yang cepat yang dilakukan oleh tenaga kesehatan sehingga perdarahan yang dialami ibu ringan. Dari 15 orang ibu yang berumur 21-35 tahun yang mengalami retensio plasenta, 14 orang ibu yang diantaranya mengalami retensio plasenta ringan, hal ini karena keadaan uterus yang masih baik dan umur ibu masih produktif ketika malahirkan sehingga mengurangi resiko perdarahan sedang. Sedangkan 1 orang ibu mengalami perdarahan sedang, hal ini karena keadaan ibu yang tidak baik dan ibu sudah memiliki paritas tinggi sehingga otot-otot rahim sudah lemah dan terjadi retensio plasenta sedang.

Hal ini sesuai dengan penelitian yang dilakukan oleh Hanna (2018). Pengaruh paritas sangat besar karena usia ibu > 35 tahun dapat tejadi komplikasi pada kehamilan, persalinan nifas. Banyak sumber menyetujui bahwa ibu yang sebelumnya memiliki tiga bayi atau lebih berisiko tinggi mengalami retensi plasenta, selain itu yang usianya lebih dario 35 tahun diketahui lebih beresiko mengalami retensi plasenta.

Menurut asumsi peneliti, umur ibu berhubungan terhadap terjadinya retensi plasenta. Hal ini diakibatkan oleh semakin tua seseorang dalam melahirkan maka otot rahim akan semakin lemah dan menurunnya kemampuan serta fungsi tubuh ibu yang semakin tua menyebabkan kematian sejumlah besar sel pada jaringan endometrium sebagai tempat implantasi tidak berfungsi dengan baik. 
Berdasarkan pengujian dengan menggunakan perbandingan Chi-Squre hitung dengan Chi-Squre tabel diketahui bahwa $\mathrm{x} 2$ hitung $=13,093$ degan tingkat kepercayaan $95 \% \alpha=$ $0,05, \mathrm{df}=1$ dan $\mathrm{X}^{2}$ tabel $=3,841$ perbandingan chi-square dengan chisquare tabel diketahui $\mathrm{X}^{2}$ hitung $>\mathrm{X}^{2}$ tabel $(13,093>3,841)$ maka dapat disimpulkan bahwa HA diterima dan HO di tolak . jadi ada hubungan antara uterus ibu dengan terjadinya retensio plasenta.

Berdasarkan tabel keadaan uterus ibu dapat diketahui bahwa dari 15 orang ibu yang memiliki uterus yang normal, mayoritas ibu yang memiliki uterus yang normal 14 orang diantaranya mengalami retensio plasenta ringan hal ini karena keadaan uterus masih baik dan masih dapat berkontraksi dengan baik, sedangkan 1 orang mengalami retensio plasenta sedang, hal ini karena uterus ibu masih baik tapi paritas sudah tinggi sehingga otot-otot rahim sudah lemah dan tidak dapat menahan plasenta dengan baik. Dari 7 orang ibu yang memiliki keadaan uterus yang tidak normal, 2 orang ibu mengalami pendarahan ringan. Hal ini karena kondisi ibu yang baik serta tidak mengalami anemia dan penanganan yang cepat dari tenaga kesehatan sehingga ibu tidak mengalami pendarahan, sedangkan 5 orang ibu mengalami pendarahan sedang hal ini karena keadaan uterus yang sudah tidak mampu lagi berkontraksi dengan baik dan otot-otot rahim yang lemah sehinga ibu mengalami pendarahan sedang.

Menurut julman (2013) ,kelainan dari uterus ,yaitu anomali dari uterus atau serviks kelemahan dan tidak efektifnya kontraksi uterus, kontraksi yang teknik dari uterus ,serta pembentukan constriction ring .uterus yang tidak dapat berkontraksi dengan baik menggangu kontraksi otot rahim sehinga plasenta tidak dapat segera lahir (retensio plasenta) dan menimbulkan pendarahan .

Menurut chaval (2014), pada uterus yang tidak normal segera setelah anak lahir ,uterus akan berhenti kontraksi namun secara perlahan tetapi progresif uterus mengecil, yang disebut retraksi, pada masa retraksi itu lembek namun serabut-serabut nya secara perlahan memendek kembali .peristiwa retraksi menyebabkan pembuluh-pembuluh darah yang berjalan di celah-celah serabut otot-otot polos rahim terjepit oleh serabut otot rahim itu sendiri bila serabut ketuban belum terlepas ,plasenta belum terlepas seluruhnya dan bekuan darah dalam rongga rahim bisa menghalangi proses retraksi yang normal dan menyebabkan banyak darah hilang .

Menurut asumsi peneliti, keadaan uterus yang tidak normal yang disebabkan adanya luka pada uterus seperti adanya luka bekas kuretase dan operasi dapat menyebabkan terjadinya retensio plasenta 
karena plasenta mencari tempat yang lebih baik di uterus sehingga plasenta melekat lebih dalam ke uterus sehingga dapat mengakibatkan sulitnya plasenta di lahirkan karena sudah melekat terlalu dalam ke otot uterus.

Berdasarkan pengujian dengan menggunakan perbandingan ChiSquare hitung dengan Chi-Square tabel diketahui bahwa $\mathrm{x} 2$ hitung $=$ 13,093 dengan tingkat kepercayaan 95\% $\alpha=0,05$. perbandingan ChiSquare hitung dengan Chi-Squrae tabel diketahaui x2 hitung $<$ x2 tabel $(13,093>5,991)$ maka dapat disimpulkan bahwa Ha diterima dan Ho ditolak. Jadi ada hubungan antara perlengketan plasenta dengan terjadinya retensio plasenta.

Berdasarkan tabel perlengketan ibu bersalin dari 17 orang ibu yang mengalami perlengketan plasenta adhesive, 15 diantaranya mengalami retensio plasenta ringan. Hal ini karena plasenta belum terlalu dalam melekat sampai ke otot rahim sehingga dapat dibantu dengan pemberian obat uteru tonita sehingga ibu hanya mengalami pendarahan ringan. Sedangkan 2 orang ibu mengalami pendaharaan sedang. Hal ini diakibatkan karena umur ibu yang sudah 35 tahun sehingga keadaan uterus sudah lemah dan terjadi perlengketan sehingga akhirnya ibu mengalami perdarahan sedang. Dari 4 orang ibu yang mengalami perlengketan plasenta ingkreta 1 diantaranya mengalami perdarahan ringan. Hal ini karena kontraksi uterus ibu masih baik, kemudian adanya pemberian obat uteru tonita yang cepat serta otot rahim masih kuat sehingga tidak terjadi pendarahan sedang. Sedangkan 3 orang ibu mengalami pendaharan sedang hal ini karena plasenta sudah melekat kedalam mio metriu sehingga masih sulit plasenta lahir walaupun sudah diberikan uteru tonita, akan tetapi karena

\section{KESIMPULAN DAN SARAN}

\section{Kesimpulan}

Berdasarkan hasil penelitian terhadap hubungan karakteristik ibu bersalin dengan terjadinya retesion plastenta puskesmas babussalam, kabupaten aceh tenggara tahun 2021, maka diambil beberapa kesimpulan sebagai berikut :Ada hubungan paritas ibu bersalin, Ada hubungan umur ibu bersalin , Ada hubungan keadaan uterus ibu bersalin , dan Ada hubungan perlengketan plasenta dengan terjadinnya retension plasenta di Puskesmas Babussalam, Kabupaten Aceh Tenggara Tahun 2021.

\section{Saran}

Bagi ibu diharapkan kepada ibu agar menjaga jarak kehamilannya dan jika umur ibu sudah > 35 tahun dan sudajh memiliki 3 anak hendaknya ibu tidak hamil lagi karena akan sangat beresiko terhadap ibu dan janin 
DAFTAR PUSTAKA

Afrizal. (2012). Penurunan Angka Kematian Ibu Belum Sesuai Target MDGs. http://www.antaranews.com

Budiarto, E. (2012). Biostatistika Untuk Kedokteran dan Kesehatan Masyarakat. EGC.

Chapman, V. (2016). Asuhan Kebidanan Persalinan dan Kelahiran. EGC.

Departemen Kesehatan, R. (2016). Riset Kesehatan Dasar. http://www.depkes.co.id

Manuaba, Ida, B. (2018). Ilmu Kebidanan Penyakit Kandungan \& Keluarga Berencana untuk Pendidikan Bidan. EGC.

HAZMI. (2015). Faktor-Faktor Yang Mempengaruhi Kejadian Perdarahan Postpartum DI RSUD Panembahan Senopati Bantul Yogyakarta. http://digilib.unisayogya.ac.id/74 5/1/Naskah Publikasi PDF.pdf

Yuliati Asif. (2017). BEBERAPA FAKTOR KEJADIAN PERDARAHAN POSTPARTUM IBU BERSALIN YANG DIRAWAT DI RUMAH SAKIT. http://eprints.undip.ac.id/56082/1
/Artikel_Jurnal_FR_PPH_Ibu_Bersalin

_Temanggung.pdf 